\title{
Stereotyping of Muslims in the mass-media of Australia and New Zealand
}

\section{Lytovchenko}

Taras Shevchenko National University of Kyiv, Kyiv, Ukraine

Corresponding author. E-mail: Daniil.lytovchenko@gmail.com

Paper received 27.10.17; Revised 02.11.17; Accepted for publication 05.11.17.

https://doi.org/10.31174/SEND-PH2017-145V41-06

\begin{abstract}
The article reviews the specific features of ethno-cultural stereotyping of Muslims in the printed media of Australia and New Zealand, investigates linguistic realization of positive and negative Muslim stereotypes, and analyzes linguistic and extra-linguistic means of ethno-cultural separation of Muslims by the representatives of Australian and New Zealand community.
\end{abstract}

Keywords: stereotype, stereotyping, ethno-cultural stereotype, Muslim stereotypes Islam, bias, media discourse.

Introduction. Throughout the latest decades with the help of the newest media, a new type of discourse appeared media discourse, which unites different elements of different media communication types. However, despite the democratization of the current mass media, the process of constructing media discourse is influenced by the social hierarchy and governmental censorship while the subjects entering the process of communication are not devoid of the stereotypical vision of the world. Hence, stereotypes still remain one of the most important factors in the construction of media reality.

A stereotype is a certain fragment of the conceptual picture of the world, mental "picture," a stable cultural national idea about an object, subject, or situation [3, p. 178]. A stereotype consists of the mental image and its verbal cover. A stereotype does not exist beyond context, and it appears during the moment of recognizing the model, which exists in the collective consciousness [4, p. 198]. Stereotypes as mental entities, which are responsible for the experience of the individual's socializing, become an intertextual category in the mass media discourse. This category connects the manifestations of mass culture, social traditions, and ideology into one whole space of media discourse [7, p. 106].

Among the existing types of stereotypes, ethnical stereotypes have acquired considerable expansion in the media environment. Since the ethnical stereotypes allow to simplify and place into certain categories and templates the social environment of a human being, this type of stereotypes is used by the media environment to depict "Foreign" and "Others" categories of population with different ethnical properties. The phenomenon of stereotypical depiction of Muslim ethnos in the English language mass media has become extremely urgent nowadays.

Brief Review of publications on the topic. Numerous scientists such as Belova, A. D. [1], Katsbert T. L. [2], Orlova, O. G. [7], Levchenko O. P. [5], Sides, J., and Gross, K. [15] researched the creation and usage of ethnostereotypes in discourse as a whole and in its media subtype as well.

The nature for the appearance of ethno-stereotypes, their influence on the construction of the media environment reality, ways of linguistic representation of stereotypes - all of these constitute central issues of studying stereotyping. The studying of stereotypical depiction of Muslims in Australian and New Zealand publications is represented by a relatively small group of researches [9], contrary to the studies of Muslim stereotyping in the US mass media. Therefore, we consider it appropriate to look at this less studied English language sphere of the world, because Australian and New Zealand media materials alike contain anti-Muslim stereotypes worth investigating.

The issue of Muslim stereotyping in the media environments of Australia and New Zealand has a number of specific traits in comparison with the similar processes in the European or North American mass media. The policy of these two countries concerning migration processes causes the presence of the relatively low numbers of refugees from the Muslim countries of the Near East (according to the data of the Migration Bureau, in 2015, every fifth Muslim refugee only received permission to relocate to Australia, and only every sixth one - to New Zealand). According to the official information, same rules of checking procedures are applied to Muslim migrants and other groups of migrants. However, the statistics of Australia's Department of Employment shows that the permissions for employment are acquired more often by the Muslims for the Eastern Asian countries (Indonesia, Malaysia, Philippines) rather than migrants from the Near East [Australia \& New Zealand Immigration Report]. Therefore, there is a tendency for prejudiced perception of Muslims, which leads to the creation of social stereotypes.

The urgency of the research is defined by the attention given to the phenomenon of ethnical stereotypes and their language design by the representatives of a wide range of disciplines (communicative linguistics, psycholinguistics, ethnolinguistics, discourse-analysis, linguocultural theory of language communication, and others, especially taking into account the current geopolitical situation.

The aim of the research is to analyze the peculiar functions of ethnic Muslim stereotypes in the media of Australia and New Zealand and to study the influence mechanisms on the public thought and the attitude of the common citizens towards the representatives of the Islamic world. As was the case in the previous researches, we used the material of regional publications in both Australia and New Zealand. They allow observing the overall picture of creation, usage, and reflection of the Muslim stereotypes in the media discourse of these countries "from inside out" since the regional press is characterized by the absence of clearly defined ethnical policies among different outlets as well as lack of their unified position regarding the Muslim population.

Materials and methods. The conscience of the modern person, their world-view and disposition are formed within the heterogeneous environment of discourse. Stereotypes as complicated linguo-mental entities, which accumulate social, psychological, and historical experiences of a 
person, function within different types of discourse. Stereotypes are part of evaluative thoughts, which characterize a human being within a particular society, influence behavior and create certain clichés directed at world interpretation [1, p. 45]. They make up traditional forms of expressing certain meanings, which became standard; a stereotype exists within the consciousness as a stable sign [2, p. 9]. However, the stability of a stereotype as a sign does not imply its correctness or truthfulness, since the essence of stereotype is prejudice and not normal objective perception.

Each type of discourse uses the process of stereotyping, which influences the formation of world-view within a person, in a certain way and with the help of peculiar means. The message is constructed from the information, which is within the media discourse. The message has to be perceived by the general audience as truthful and influence the said audience in a particular way. Such an effect is achieved with the help of numerous repetitions of standardized verbal units, which leads to the creation of media stereotypes. [15, p. 585].

The basis of stereotypes creation in media discourse is comprised of social prejudices, which receive new meaning in a certain contextual or cultural surroundings [11, p. 436]. Ethnical stereotypes as evaluative judgments on the representatives of other ethne, which are used by journalists, reflect the specificity of the modern selfconsciousness of nations and ethne, the ethnical picture of the world typical for the current political situation. Verbalized ethnical stereotypes explicitly and implicitly reflect their specificity in the form of connotative evaluation. The aim of the evident stereotypical perception in a language usually becomes the axiological negative "Foreign" which is distanced from the positive nature of "Native" [5, p. 42]. The national identity, which includes ethnical stereotypes, presupposes the realization of differences of non-foreign, own group from others and increases the feeling of belonging and sympathy towards one's own group [2, p. 7].

The real communication situation can differ from the accepted standards of ideas about a subject or object of stereotyping. However, if the process of intercultural communication transforms into the interaction of an individual (carrier of particular ideas) with the information source (for examples, mass media or other outlets), the process of stereotypical thinking is launched involuntarily, and it is difficult to control since a human being perceives the object of reality's reflection rather than the subject - a human being of a different culture.

The information in the various types of media is provided in such a way so as to influence the audience covertly and to create a message that would be perceived as truthful, normal, and implicit [8, p. 79]. The means of structuring the media message with the aim of influencing the audience through stereotypes include: presence of key word-stereotypes consistently spread across the text of the given article; usage of specific prejudiced vocabulary; high degree of creolizing and visualization of texts; saturation with graphic elements, means of expressiveness and amplification.

Media sources operate with the brightest stereotypical images in order to amplify the effect on the target audience, to change public opinion and impose the masses positive or, more often, negative ideas about a certain focus-group. One of the most popular focus-groups, which are depicted with the help of stereotypes, consists of the representative from Muslim environment. The ways, in which Western cultures attempt to "get acquainted" with the Muslims and Islam, are mostly grounded on the cultural tendency of orientalism or orientology; historical perception of nonwestern cultures by Western cultures as foreign, different, other, far, obsolete, irrational, and passive [14]. Against the background of such an approach and the current geopolitical situation of the latest decades we encounter the prevalence of "traditional" and newly formed Muslim stereotypes, particularly in the English language media environment.

We reviewed the means of depicting Muslims by the American media in the article "Realization of ethnocultural stereotyping of Muslims in the manipulative technologies of English language mass-media." Ideas of Muslims in the media discourse within the US mass media, as a rule, concentrated on the themes of terrorism and violence thus generating negative stereotypes on Muslims. After the 9/11 tragedy, the media environment is imposing the stereotypical image of Muslims on the audience as they are depicted more often as potential terrorists [12, p. 12]. Since such a depiction is connected to the policies of the US and the geopolitical situation, it is very difficult to fight such stereotypical anti-Muslim notions, because the public easily accepts stereotypes as only possible reality [6, p. 436]. However, not all publications occupy such a position of principle concerning the negative stereotyping of Muslims and Islam as a whole.

Results and their discussion. The media in Australia and New Zealand differ through their more balanced and aloof approach towards the coverage of Muslim issues in the mass media. It can be explain, first of all, by the geographical remoteness from the arena of primary geopolitical conflicts and terroristic acts, which are often connected to the Muslims. Secondly, the Muslim community of Australia and New Zealand is far from being homogeneous, for it consists of immigrants from Muslim countries of the Asian-Pacific region with few former dwellers of Europe and Near East. Another important factor is that throughout the last 25 years, neither Australia nor New Zealand experience terroristic acts on the basis of ethnic differentiation of society in comparison to Europe and USA, therefore, the attitude towards Muslim minorities does not bear extremist character.

Nonetheless, if one is to compare the attitude towards Muslims in Australia and New Zealand separately and in more detail, it is possible to observe considerable differences in the perception of this ethnic community and its coverage in the mass media. If one is to observe the treatment of Muslims in Australia and their depiction in the media materials, the tendency of non-tolerance towards Muslims from some of the representatives of Australian society is easily noticeable. This lack of tolerance can later transform into hostility or even extremism. On the lexical level, it is conveyed through rather restrained, neutral messages, which aim at the status of being objective information:

A MUSLIM family from the Upper Hunter has been the subject of threats and online abuse after a far-right antiIslamic social media page posted clandestine photos of 
them outside of their home <... It was accompanied with the caption "Not wanted and not welcome. Put your daughters inside." [The Herald, Newcastle AU, December 4, 2015].

It is clear that the author is trying to withdraw while describing the fact that Muslims, who are associated with the image of the "Foreign" or "Enemies" for the small part of the society, become the objects of persecution on the basis of ethnicity. The article lacks emotional elements of indignation concerning this unacceptable situation such as the threats to the people of Australia and their children. The newspaper cites a threatening sentence "Put your daughters inside," which creates a worrying impression with politely chosen words, which, if regarded outside this particular context, all belong to fully neutral vocabulary. In the context of the article, however, such vocabulary conjures negative imagery.

It is clear from the excerpt above that the usual citizens are not suffering from any Islamic threat in Australia, but the representatives of Muslim minorities are in actual danger of direct offences and threats simply due to sharing the same faith with Arab terrorists. We can observe in a different excerpt that some Muslims do not take such threats lightly:

"My wife is pretty cautious about where she goes and what she does $<\ldots>$ It's not an enjoyable feeling to feel threatened in your own home." Mr. Mehtar said the Southern River Islamic mosque will swing open its doors on Saturday for the general public. "If there is something troubling you or on your mind and you feel that Muslims are such and such, come and ask, come and meet us [Collie Mail AU, October 21, 2014].

Stereotypes regarding Muslims in this article are expressed euphemistically as the author and the interlocutor are reserved in their statements (Muslims are such and such).In the last sentence there is evident reiteration of vocabulary unites for the sake of amplifying the call of action and assurance that Muslims of Australia are open to a dialogue with those, who may treat them with animosity. The fact of threats is depicted with maximum politeness and reservation. The author re-thinks the known idiom "my home my castle" and notes that Muslims cannot even feel safe in their homes (feel threatened in your own home).

Examples provided above are taken from publications, which bear the reputation of objective press. Such examples are characterized not only by restraint and extremely tolerant vocabulary but also attempts to provide the information without bias or prejudice. If one is to consider the articles from "tabloids," meaning rather unknown publications with smaller circulation, mostly popular in more remote regions of Australia, the open distortion of facts (or their complete fabrication) with the aim of manipulating the readers and making them to perceive Muslims negative in congruency with existing social stereotypes becomes swiftly evident:

"...many of the Aboriginal people in northern Australia are being targeted by Muslims and in some cases are being paid to convert to Islam $<\ldots>$ Our concern with that is, the Muslim belief, that converting the first peoples of the land to Islam means that the land belongs to Allah, and Islam should be the only religion $\langle\ldots\rangle$ What we don't support is their hijacking of our laws and our system," she said [Katherine Times AU, August 30, 2013].
The message is structured in the following manner: the first sentence is the claim for sensation in the pieces of news, which is given to the readers. Australian aborigines are contrasted against Muslims, who arrived to the country recently and attempt to convert the aborigines to their faith by offering money. The development of events comes next - an absurd assumption that Australian land can become in such a way Islamic and would belong to Allah. In the culmination of the article, words of an "expert" are cited, who divides dwellers of the country into "Native" (our laws and our system) and "Foreign" (their hijacking), which creates the stereotype of a dishonest, perfidious Muslim, who tries to grab their land with whichever means necessary.

Apart from the tendency to radicalize the public thought concerning Muslims through imposing the stereotypes of "dishonest" Muslims, who should be justly punished, there are numerous publications with "rational" stereotypes regarding Muslims. Such a type of stereotypes presupposes the presence of the distanced focus-group "Foreign" (for examples, members of terroristic organizations - radical Muslims belonging to Muslim Brotherhood, ISIS, AlQaeda, and other terroristic groups), and, at the same time, empathize with the problems of the Muslim "peaceful" community in Australia:

Coptic Christians demonstrate in Sydney on Saturday against Egypt's Muslim Brotherhood. "We are gathered here to oppose the crimes against the humanity that have been committed by the Muslim Brotherhood, which has been largely ignored by Western leaders and by the mass media." [Collie Mail AU, August 24, 2013].

On the lexical level, the article features evident oppositions Christian - Muslim, Muslim - Western, which define the belonging to categories "Native" - "Foreign" and at the same time separate Australian Muslims from the crimes of the Egyptian Muslims. As far as the trigger concepts are concerned, the role of the trigger is performed by the phrase Muslim Brotherhood, which immediately conjures unpleasant associations and identification of Muslim-Arabs with terrorists. The same trigger is evident in the following excerpt from a New Zealand publication:

" $<\ldots$.. $>$ al-Qaida militants killed at least 28 people in an attack on a hotel and cafe popular with foreigners $<\ldots>$ in Burkina Faso, a largely Muslim country that had managed to avoid the kinds of jihadist attacks that have destabilized neighboring Mali since 2012. In a separate incident two Australian humanitarian workers were kidnapped by extremists in northern Burkina Faso [New Zealand Herald, January 17, 2016].

The names of terroristic groups immediately launch the recognition mechanism in the consciousness of the reader and identify with the stable associations, which are also present in the text of the article to amplify the influence of the stereotype on the recipient: al-Qaida-Muslim - attack - jihadist attacks - extremists - militants. The similar associative series of words bear the character of stereotypical generalization, which concerns the perception of terroristic organizations' names by Australians and New Zealanders and subconsciously influences the construction of their mental image. Such associative word series are amplified by epithets, comparisons, metaphors, and other ways of expression: 
$<\ldots>$ Indonesia's militants have been seen as increasingly weak and fragmented. Their identification with the Islamic State group in distant Syria is an attempt to change those perceptions by linking to a network known for brutal, headline-grabbing attacks [New Zealand Herald, January 15, 2016].

Another theme in the media discourse of Australia and New Zealand, which features the functioning of Muslim stereotypes, is the political component of the process of localizing Muslim communities in these two countries. The problem of distorted, stereotypical perception of Muslims in the world led to the willingness of Australian and New Zealand politicians to manipulate the consciousness of the electorate through "flirting" with the Muslim issue. In the United States, such a tendency usually results in calling to remove Muslims from the country, to localize them, but in the Australian region the image of a Muslim during the election period is turned into a stereotypical depiction of a human being, who has nowhere to go, who requires, help, commiseration and financial investments. Politicians, who are in opposition towards such a non-covert manipulation of the electorate, even created a name for this phenomenon - muspandering. The newly created stereotype functions in numerous speeches and denotes attention to the problems of Muslims, which becomes actively during the election periods only with the aim to increase the number of potential votes:

Mr Robinson used Twitter to ask his followers if Australian politicians were guilty of "muspandering" in a similar way US politicians were guilty of pandering to Hispanics. In a series of tweets, Mr Robinson blasted politicians for pandering to Islam and not linking the religion directly to terrorism. One tweet also backed former PM Tony Abbott's recent calls for Islamic reforms and said state MPS were too lenient in their comments on Islam [Redland City Bulletin AU, December 15, 2015].

The majority of the politicians are not shy to use "muspandering" and in their speeches combine concepts, which denote key values for the representatives of the Western world. In such a way, they level the negative stereotyping of Muslims and show them as welcome guests in Australia. Such speeches are filled with graphic elements, pretentiousness and histrionics:

Opposition Leader Tony Abbott has used his first set speech on the campaign trail to appeal to western Sydney's Muslim community $<\ldots>$ "[Our] multiculturalism is a beacon of hope to a troubled and divided world," he said. "People from all around the four corners of this earth have come to this country of ours to be welcomed by us and to build a better life in freedom, for themselves and their children." [Augusta-Margaret River Mail AU, August 5, 2013].

It is evident that the notion multiculturalism stands near the concept Muslim, which acquires normalized, rational meaning and s no longer associated with terrorism. Graphic elements (beacon of hope to a troubled and divided world, from all around the four corners of this earth) aim to confuse the audience with nice-sounding template phrases, which would help the speech maker to make a positive and intellectual impression.

New Zealand press when using Muslim stereotypes uses additional method, which was nowhere to be found in
Australian publications. The method is - letters from readers to editorial staff and their monologue in front of the imaginary audience regarding the problem, which was touched upon in the last issues of the newspaper. People openly use prejudiced knowledge about Muslims and Islam, which they consider true to a certainty:

Being born here in New Zealand to French parents, I must have a say in these horrible killings of innocent civilians by radical Muslims $<\ldots>$ they infiltrate and call Christians "infidels". Because of their fanatical religious beliefs, this conflict unfortunately will continue. It can happen anywhere in the world [Hawkes Bay Today NZ, January 25, 2016].

We observe yet again the presence of another opposition Muslims - Christians, however, the reader insists that the Muslims are treating the Christians as the "infidels" even though it is far from objective reality. We notice the distortion of facts through stereotypical ideas about Muslims. The style of the letter author differs from that of the newspaper author: the vocabulary is simpler and the graphic imagery is almost absent. The hidden subtext of the message is also nowhere to be found.

In the excerpts above and about to be presented below, the readers, who write letters to the editorial staff, stress on their right to voice their opinion and in such a way proclaim the active civil stance of New Zealanders (I must have a say, I believe Gisborne people need to be informed). It is necessary to keep in mind that such activity is explained through the desire to turn attention to oneself and one's own country, for we see in the next letter that due to New Zealand's geographic remoteness its dwellers perceive it as an isolated country, and the places of modern conflicts and political events as the centre of the world:

I believe Gisborne people need to be informed about the issue of fundamentalist Islam $<\ldots>$ many Muslims aim to establish a caliphate worldwide $<\ldots>$ we need to know what Sharia law and fundamentalist Muslim beliefs involve. Let not our isolation as a country be our downfall [The Gisborne Herald NZ, January 25, 2016].

Conclusions. In such a way, we found out that the formation and usage of Muslim stereotypes in Australian and New Zealand media environment has a number of peculiarities in comparison with the media discourse in the United States. Politicians use manipulative technologies to turn negative stereotypes into neutral and create the effect of empathy towards Muslim migrants with the help of uniting polar concepts. At the same time, there is evidence of insignificant displays of aggression and extremism directed at Muslims among the local population, mainly the members of radical organizations. A change of the stereotype's vector happens during the depiction of such situations in the mass media, and the Muslims appear not as enemies but as victims of violence and threats. A considerable number of media materials is aimed at rationalizing Muslim stereotypes: Australian Muslims enter the "Native" group while the "remote" Muslims of the Near East constitute the "Foreign," "Others" category. New Zealand publications, in comparison with the Australian ones, possess more peripheral traits, which leaves a mark on the delivery of information on Muslims and the usage of "usual" stereotypes. 


\section{ЛИТЕРАТУРА}

1. Бєлова А.Д. Лексична семантика і міжкультурні стереотипи / А.Д.Бєлова // Мовні і концептуальні картини світу. - К.: КНУ, 2002. - С. 43-54.

2. Кацберт Т.Л. Національні стереотипи в англо-німецьких відносинах: лінгвокультурний аспект: дис. ... канд. філол. наук: 10.02.04 / Кацберт Т.Л. - К., 2007. - 295 с.

3. Кузьменко О. Функціонування етнічних стереотипів в Інтернет-просторі: польсько-український контекст // O.Kuzmenko. - Rocznik Europejskiego Kolegium Polskich i Ukraińsjich Uniwersytetow. Lublin: Wyd. UMCS, - 2010. - T. 6. - C. 197-204.

4. Левченко О.П. Етнічні стереотипи у публіцистичному тексті // O.Levchenko. - Slowo. Tekst. Czas: Materialy Konferencji Naukowej. - Szczecin, 2001. - C. 41-43.

5. Литовченко Д. Етнокультурна стереотипізація мусульман у маніпулятивних технологіях англомовних мас-медіа // Д.Литовченко. - Мовні і концептуальні картини світу: Зб.наук.праць. КНУ ім.Т.Г.Шевченка: Вид. "Київський університет", 2015. - Вип. 1 (52). - С. 428-438.

6. Орлова О.Г. Стереотип в публицистическом дискурсе // О.Орлова. - Вестник НГУ. Серия: История, филология. 2012. - Том 11, выпуск 6. - С.104-109.

7. Силантьев И. В. Дискурс и жанр // И. Силантьев. - Вестн. Новосиб. гос. ун-та, Серия: История, филология. -
Новосибирск, 2010. - Т. 9, вып. 6: Журналистика. - С. 78 84.

8. Akbarzadeh Sh. The Representation of Islam and Muslims in the Media // Monash University: School of Political and Social Inquiry. - November 2005. - $41 \mathrm{p}$.

9. Australia \& New Zealand Immigration Report: [E. pecypc]. Режим доступу: http://www.border.gov.au/ReportsandPublications/Documents/ discussion-papers/Migration-Programme 2015-16-DiscussionPaper.pdf

10. Levey, Geoffrey Brahm, and Modood, Tariq. The Muhammad Cartoons and Multicultural Democracies. - Ethnicities 9.3. 2009. - P. 427-447.

11. Merskin, Debra L. Media, Minorities, and Meaning: a Critical Introduction. New York: Peter Lang, 2011. - P. 9-21.

12. Rane H., Ewart J., Abdala M. Islam and the Australian News Media: Melbourne University Press, 2010. - 259 p.

13. Shahzad, Ali. US print media and portrayal of Muslim world: A case study of Newsweek and Times (1991-2001). - Ph.D. Dissertation. - Multan: Bahauddin Zakariya University, 2009. http://prr.hec.gov.pk/Thesis/465S.pdf

14. Sides J., Gross K. Stereotypes of Muslims and Support of the War of Terror // The Journal of Politics. Volume 75. - Issue 03. - July 2013. - pp. 583-598.

\section{REFERENCES}

1. Belova, A. D. "Lexical semantics and inter-cultural stereotypes." Linguistic and conceptual pictures of the

world. KNU Press, 2002. Print. Pp - 43-54.

2. Katsbert, T. L. National stereotypes in English-German relations: linguocultural aspect. Dissertation: 10.02.04. Kyiv, 2007. Print. P. - 295.

3. Kuzmenko, O. Functioning of ethnic stereotypes in the Internet environment: Polish-Ukrainian context. European Collegium of Polish and Ukrainian Universities yearbook, vol. 6. - Lublin Wyd. UMCS, 2010. Print. Pp - 197-204.
4. Levchenko, O. P. Ethnic stereotypes in publicistic texts. Word. Text. Time: Scientific Conference Material. - Szczecin, 2001. Print. Pp - 41-43.

5. Lytovchenko, D. Ethnocultural stereotyping of Muslims in the manipulative technologies of English language mass media. Linguistic and conceptual pictures of the world, issue 1 (52). Kyiv National University Press, 2015. Print. Pp - 428-438.

6. Orlova, O. G. Stereotype in publicistic discourse // NSU Bulletin. Series: History, philology, vol. 11, no. 6, 2012. Print. Pp 104-109.

7. Sylantyev, I. V. Discourse and genre. NSU Bulletin. Series: History, philology, vol. 9, no. 6, 2010. Print. Pp-78-84.

\section{Стереотипизация мусульман в массмедиа Австралии и Новой Зеландии}

\section{Д. Литовченко}

Аннотация. В статье рассматриваются особенности этнокультурной стереотипизации мусульман в печатных изданиях Австралии и Новой Зеландии, исследуется лингвистическое оформление положительных и отрицательных стереотипов, изображающих мусульман, исследуются лингвистические и экстралингвистические средства этнокультурного отделения мусульман представителями австралийского и новозеландского медиапространства.

Ключевые слова: стереотип, стереотипизация, этнокультурный стереотип, антимусульманские стереотипь, Ислам, предубеждения, медиадискурс. 